\title{
Analisis Konten Buku Teks Geografi SMA Menggunakan Model Beck \& Mckeown
}

\author{
Furqan Ishak Aksa*, Ramdan Afrian**, Jofrishal** \\ * Pendidikan Geografi, FKIP Universitas Samudra \\ ** Pendidikan Kimia, FKIP Universitas Samudra
}

\section{INFO ARTIKEL}

Riwayat Artikel:

Diterima: 18-6-2017

Disetujui: 4-12-2017

\section{Kata kunci: \\ Analisis Konten; Buku Teks \\ Geografi; Model Beck \& \\ McKeown}

\author{
Alamat Korespondensi: \\ Furqan Ishak Aksa \\ Pendidikan Geografi \\ FKIP Universitas Samudra \\ Jalan Meurandeh, Langsa Lama, Kota Langsa, Aceh \\ E-mail: furqonishaksa@unsam.ac.id
}

\begin{abstract}
Abstrak: Penelitian ini didasari oleh besarnya peran buku teks dalam pembelajaran di sekolah. Kondisi tersebut menuntut tersedianya buku teks berkualitas yang mampu mengembangkan kemampuan berfikir kritis siswa. Penelitian ini bertujuan untuk mengetahui konten (isi) buku teks geografi yang digunakan oleh siswa dan guru SMA di Kota Langsa. Penelitian ini menggunakan metode analisis deskriptif. Analisis isi (konten) menggunakan model pengembangan kognitif Beck \& McKeown yang dimodifikasi menjadi enam langkah. Hasil penelitian menunjukkan bahwa buku teks geografi SMA karangan $K$. Wardiyatmoko hanya mengandung fakta, data, dan konsep. Merujuk pada kriteria pengembangan kognitif yang dikembangkan oleh Beck \& McKeown, buku teks tersebut tidak valid dan dapat digolongkan Not close look at problematic discussion yakni buku teks yang tidak dapat membantu siswa untuk belajar menyelesaikan masalah dan berfikir kreatif. Kondisi ini tentu akan membuat pembelajaran geografi di sekolah tidak berhasil melahirkan lulusan yang mampu berfikir kritis sesuai dengan tuntutan pembelajaran pada abad 21.
\end{abstract}

\section{PENDAHULUAN}

Buku teks digunakan hampir di berbagai jenjang pendidikan, mulai dari tingkat dasar, menengah hingga atas. Hal ini disebabkan oleh besarnya peran buku teks dalam pembelajaran.Buku teks berperan penting dalam mengaplikasikan tujuan yang terkandung dalam kurikulum ke dalam bentuk yang lebih kongkrit (Lee \& Catling, 2016). Oleh kerena itu, buku teks masih dianggap memiliki peran yang sangat vital dalam mencapai tujuan pendidikan sesuai dengan yang dikehendaki oleh kurikulum.

Besarnya peranan buku teks dalam pembelajaran membuat guru dan siswa sangat bergantung pada buku teks.Hal ini mengakibatkan pembelajaran yang berlangsung di ruang kelas sangat dipengaruhui oleh konten (isi) buku teks.Semakin baik isi (konten) yang terkandung dalam buku teks, semakin baik pula kualitas pembelajaran.

Buku teks yang baik adalah yang dapat merangsang siswa untuk berfikir kritis dan kreatif (Lee \& Catling, 2016). Konten (isi) Buku teks jenis tersebut tentunya tidak hanya didominasi oleh fakta/data dan konsep. Namun, menyajikan berbagai masalah yang dapat dipecahkan siswa (Boehrer \& Linsky, 1990). 
Sebagai bidang ilmu yang mempelajari interaksi antara alam dan manusia (Harper, 1990), pembelajaran geografi memerlukan banyak permasalahan yang harus diintegrasikan ke dalam buku teks. Hal ini sangat penting dilakukan untuk meningkatkan kemampuan berfikir kritis, siswa harus sering dilatih dengan menyajikan berbagai permasalahan (Jitendra, et al, 2001).

Namun demikian, hasil penelitian di Inggris menunjukkan bahwa kualitas buku teks geografi yang digunakan oleh siswa dan guru hanya memuat fakta, data, dan konsep (Tindal, Nolet, dan Blake,1992 dalam Jitendra, 2001). Kondisi ini tentu akan membuat pembelajaran geografi di sekolah tidak berhasil melahirkan lulusan yang mampu berfikir kritis sesuai dengan tuntutan pembelajaran pada abad 21 (Shamir, et al, 2008 ;Walkington, et al, 2017).

Bedasarkan permasalahan tersebut (rendahnya kualitas buku teks geografi di beberapa negara yang hanya memuat fakta, data, dan generalisasi) penulis ingin melakukan analisis konten (isi) terhadap buku teks geografi SMA yang digunakan di Kota Langsa. Hal ini bertujuan untuk mengetahui kandungan buku teks geografi SMA. Penelitian ini menggunakan model kriteria pengembangan kognitif yang dikembangkan oleh Beck dan McKeown.

Model tersebut terdiri dari sepuluh kriteria yang dapat digunakan untuk melakukan analisis ketercernaan konten (isi) buku teks geografi SMA. Kesepuluh kriteria tersebut yaitu, Pertama, Not close look at problematic discussion, buku teks dapat dikatagorikan kedalam jenis ini apabila konten (isi) buku teks tidak menyajikan permasalahan yang dapat didiskusikan oleh siswa. Kedua, To Many Concept, isi buku teks yang banyak sekali menyajikan konsep dalam setiap paragrafnya. Ketiga, What's The Point yakni konten (isi) buku teks yang tidak mengandung wacana yang jelas (eksplisit). Keempat, Aside That Overwhelm the purpose, yakni konten (isi) buku teks memuat tujuan-tujuan lain selain tujuan utama.

Kelima, Inadequate examples and comparasions yakni konten (isi) buku teks banyak menyajikan contoh-contoh perbandingan yang tidak sesuai dengan konsep. Keenam, Couse Without Consequence yakni konsep yang disajikan menyulitkan siswa memahami hubungan sebab akibat. Ketujuh, No Sense Of Time yakni konten (isi) buku teks yang disajikan tidak memuat fenomena sesuai dengan kronologi waktu (urutan waktu). Kedelapan, Poorly ordered componens an explanation yakni konsep yang disajikan tidak tersusun secara logis. Kesembilan, Inadequate explanation yakni penjelasan konsep dalam buku teks sulit dipahami siswa. Kesepuluh, Understate presentation of important information yakni konten (isi) buku teks tidak memberikan penekanan terhadap konsep - konsep penting.

Namun demikian, penelitian ini tidak mengadopsi semua kriteria pengembangan kognitif tersebut. Model tersebut dimodifikasi menjadi enam kriteria yaitu (1) Not close look at problematic discussion, (2) To Many Concept, (3) What's The Point, (4) Aside That Overwhelm the purpose (5) Inadequate examples and comparasions, (6) Poorly ordered componens an explanation. Hal ini disesuaikan dengan tujuan penelitian karena tidak semua kriteria model tersebut sesuai dengan konten buku teks geografi di Indonesia yang ada saat ini.

\section{METODE}

Penelitian ini menggunakan metode analisis deskriptif. Analisis dilakukan dengan menggunakan bebera paprosedur, yaitu: Pertama, Memilih buku teks yang akan dianalisis. Dalam penelitian ini, peneliti mengambil buku teks geografi karangan K. Wardiyatmoko yang diterbitkan oleh Erlangga. Buku teks tersebut dipilih berdasarkan konsultasi dengan guru serta dengan mempertimbangkan banyaknya digunakan oleh guru dan siswa SMA di Kota Langsa. Hal ini dapat dilihat pada tabel berikut: 
Tabel 1.1 Penggunaan Buku Teks Geografi SMA di Kota Langsa

\begin{tabular}{cll}
\hline No & \multicolumn{1}{c}{ Nama Sekolah } & \multicolumn{1}{c}{ Buku Geografi Yang Digunakan } \\
\hline 1 & SMAN 1 Langsa & Penerbit Erlangga karangan K. \\
& & Wardiyatmoko \\
2 & SMAN 2 Langsa & Penerbit Erlangga karangan K. \\
& & Wardiyatmoko \\
3 & SMAN 3 Langsa & Penerbit Erlangga karangan K. \\
& & Wardiyatmoko \\
4 & SMAN 4 Langsa & Penerbit Erlangga karangan K. \\
& & Wardiyatmoko \\
5 & SMAS Cut Nyak Dien & Penerbit Erlangga karangan K. \\
& & Wardiyatmoko \\
6 & SMAS Jaya Langsa & Penerbit Erlangga karangan K. \\
& & Wardiyatmoko \\
\hline
\end{tabular}

Sumber: Hasil Observasi Tahun 2016

Kedua, Menganalisis setiap sub bab yang terkandung dalam buku teks, (3) menyajikan hasil analisis, (4) Interpetasi temuan hasil analisis dengan menggunakan kriteria pengembangan kognitif yang dikembangkan oleh Beck dan McKeown yang dimodifikasi menjadi 6 katagori sesuai dengan tujuan penelitian ini. Instrumen yang digunakan dalam melakukan analisis konten adalah sebagai berikut:

Identitas Buku

Pengarang

Penerbit

Kelas

\begin{tabular}{|c|c|c|c|c|c|c|}
\hline \multirow{2}{*}{ Kode } & \multicolumn{6}{|c|}{ Jumlah Kesalahan } \\
\hline & BAB 1 & BAB 2 & BAB 3 & BAB 4 & BAB 5 & BAB 6 \\
\hline 1 & & & & & & \\
\hline 2 & & & & & & \\
\hline 3 & & & & & & \\
\hline 4 & & & & & & \\
\hline 5 & & & & & & \\
\hline 6 & & & & & & \\
\hline
\end{tabular}

Keterangan:

Kode 1 : Not close look at problematic discussion

Kode 2 : To Many Concept

Kode 3 : What's The Point

Kode 4 : Aside That Overwhelm the purpose

Kode 5 : Inadequate examples and comparasions

Kode 6 : Poorly ordered componens an explanation

Setelah data dikumpulkan, hasil analisis tersebut diinterpretasi dengan rubrik ketercernaan isi buku teks yang dikembangkan oleh Purwanto (2001) berikut: 
Rubrik Ketercernaan Isi Bahan Pelajaran

(Ketercernaan analitik)

\section{Kode: 1}

Kategori: Not close look at a problematic discussion

Deskripsi Buku teks yang valid mampu menyajikan bahan pelajaran yang bermanfaat untuk bekal siswa dalam mendiskusikan permasalahan. Apabila buku teks geografi tidak mampu menyajikan bahan pelajaran yang bermanfaat untuk bekal diskusi, maka buku tersebut tergolong dalam kategori ini.

Kode: 2

Kategori: Too many concept

Deskripsi: dan seterusnya sampai kode 6

Konten buku teks geografi SMA dapat dikatagorikan valid apabila memiliki kesalahan (frekuensi 0) dari 6 kategori kesalahan yang ditentukan berdasarkan model pengembangan kognitif oleh Beck dan Mckeown (Purwanto, 2001).

\section{HASIL}

Hasil analisis konten (isi) buku teks geografi SMA dapat dilihat pada tabel 1.2 berikut:

Tabel 1.2. Hasil analisis konten (isi) buku teks geografi karangan $\mathrm{K}$.

\section{Wardiyatmoko}

\begin{tabular}{|c|c|c|c|c|c|c|}
\hline \multirow{2}{*}{$\begin{array}{l}\text { Ko } \\
\text { de }\end{array}$} & \multicolumn{6}{|c|}{ Jumlah Kesalahan } \\
\hline & BAB 1 & BAB 2 & BAB 3 & BAB 4 & BAB 5 & BAB 6 \\
\hline 1 & $\begin{array}{l}\text { Tidak } \\
\text { disajikan } \\
\text { permasalahan }\end{array}$ & $\begin{array}{l}\text { Tidak } \\
\text { disajikan } \\
\text { permasalahan }\end{array}$ & $\begin{array}{l}\text { Tidak } \\
\text { disajikan } \\
\text { permasalahan }\end{array}$ & $\begin{array}{l}\text { Tidak } \\
\text { disajikan } \\
\text { permasalahan }\end{array}$ & $\begin{array}{l}\text { Tidak } \\
\text { disajikan } \\
\text { permasalahan }\end{array}$ & $\begin{array}{l}\text { Tidak } \\
\text { disajikan } \\
\text { permasalahan }\end{array}$ \\
\hline 2 & 45 konsep & 50 Konsep & 55 Konsep & 43 Konsep & 45 Konsep & 50 Konsep \\
\hline 3 & 10 & 15 & 13 & 12 & 15 & 11 \\
\hline 4 & $\begin{array}{l}5 \text { Paragraf } \\
\text { mengandung } \\
\text { lebih dari satu } \\
\text { ide pokok }\end{array}$ & $\begin{array}{l}8 \text { Paragraf } \\
\text { mengandung } \\
\text { lebih dari satu } \\
\text { ide pokok }\end{array}$ & $\begin{array}{l}7 \text { Paragraf } \\
\text { mengandung } \\
\text { lebih dari satu } \\
\text { ide pokok }\end{array}$ & $\begin{array}{l}9 \text { Paragraf } \\
\text { mengandung } \\
\text { lebih dari satu } \\
\text { ide pokok }\end{array}$ & $\begin{array}{l}10 \text { Paragraf } \\
\text { mengandung } \\
\text { lebih dari satu } \\
\text { ide pokok }\end{array}$ & $\begin{array}{l}8 \text { Paragraf } \\
\text { mengandung } \\
\text { lebih dari satu } \\
\text { ide pokok }\end{array}$ \\
\hline 5 & 3 & 2 & 4 & 3 & 5 & $4^{1}$ \\
\hline 6 & 2 paragraf & 4 paragraf & 3 paragraf & 4 paragraf & 6 paragraf & 3 paragraf \\
\hline
\end{tabular}

Keterangan:

Kode 1: Not close look at problematic discussion

Kode 2 : To Many Concept

Kode 3: What's The Point

Kode 4: Aside That Overwhelm the purpose

Kode 5: Inadequate examples and comparasions

Kode 6 : Poorly ordered componens an explanation

Dari tabel 1.2 dapat diketahui bahwa banyak ditemukan juga beberapa paragraf yang mengandung ide pokok lebih dari satu. Paling banyak ditemukan pada BAB 5. Selain itu, ditemukan juga penyajian contoh yang tidak sesuai dengan konten. Namun, yang paling 
mendasar adalah semua bab dalam buku teks geografi karangan K. Wardiyatmoko kelas XII tidak menyajikan permasalahan yang dapat didiskusikan oleh siswa. Hampir keseluruhan isi buku teks hanya memuat fakta dan data serta konsep. Berdasarkan kriteria pengembangan kognitif yang dikemukakan oleh Beck dan McKeown buku tersebut termasuk katagori tidak valid dan tergolong Not close look at problematic discussion. Buku teks yang tidak dapat memfasilitasi siswa untuk belajar menyelesaikan masalah.

\section{HASIL DAN PEMBAHASAN}

Temuan dari analisis buku teks geografi SMA tersebut adalah banyaknya kandungan fakta, data, dan konsep. Hal ini diduga penulis buku teks kurang memahami tujuan dari kurikulum yang terkandung dalam kompetensi dasar. Merujuk pada kurikulum 2013 untuk bidang studi geografi diketahui bahwa tujuan yang ingin dicapai dalam pembelajaran geografi tidak hanya ranah kognitif tingkat pengetahuan dan pemahaman. Kurikulum menghendaki siswa mampu berfikir kritis dan analitis.

Kondisi konten buku teks geografi yang hanya memuat data, fakta, dan konsep akan berpengaruh besar terhadap pembelajaran di kelas. Buku teks yang hanya mengandung kumpulan fakta dan data akan membuat pembelajaran berpusat pada guru (Lee \& Catlin, 2016; Jitendra, et al, 2001). Hal ini membuat pembelajaran geografi tidak lebih dari menghafal fakta dan konsep.

Di samping itu, konten buku teks geografi yang hanya terdiri dari fakta dan terlalu banyak konsep bertentangan dengan tujuan utama pembelajaran geografi di sekolah. Pada prinsipnya pembelajaran geografi bertujuan untuk membentuk geocapabilities yang meliputi: kemampuan imajinasi geografi, kemampuan berfikir integratif dengan lingkungan, dan berfikir spasial (Walkington, H., Dyer, S., Solem, M., Haigh, M.,\& Waddington, 2017).

Kemampuan imajinasi geografi menutut siswa untuk dapat memandang ruang yang memiliki variasi antara satu tempat dengan wilayah lain dengan sudut pandang geografi (Walkington, H., Dyer, S., Solem, M., Haigh, M.,\& Waddington, 2017). Untuk mengasah kemampuan tersebut, siswa harus dilatih dengan menyajikan masalah, misalnya dengan menggunakan data demografi siswa dapat menganalisis permasalahan migrasi yang terjadi pada suatu daerah.

Kemudian, kemampuan berfikir integratif dengan lingkungan menuntut siswa memiliki respon terhadap isu - isu lingkungan di sekitarnya (Kemp; Mellor; Kotter; dan Oosthoek, 2012 ). Hal ini dapat membuat siswa peka terhadap permasalahan lingkungan yang terjadi di sekitar mereka akibat dari interaksi manusia dengan alam.

Selanjutnya, kemampuan berfikir spasial menuntut siswa mengenali pola variasi lokasi di permukaan bumi. Dalam melihat suatu fenomena geosfer yang terjadi di permukaan bumi, pemahaman siswa bukan hanya apa dan dimana, melainkan mengapa fenomena tersebut terjadi di wilayah itu (Walkington, H., Dyer, S., Solem, M., Haigh, M.,\& Waddington, 2017).

Kemampuan tersebut tentu tidak dapat dicapai oleh siswa dengan menggunakan buku teks geografi yang didominasi oleh fakta dan konsep. Oleh karena itu, disarankan kepada guru geografi untuk dapat mengembangkan pembelajaran di kelas tidak mengacu pada buku teks. Guru dituntut untuk kreatif dalam mengelola pembelajaran dengan menerapkan model Problem Based Learning untuk meningkatkan kemampuan berfikir kritis siswa.

Selain itu, diperlukan upaya serius dari pemerintah untuk menertibkan buku teks geografi yang ditulis tanpa menggunakan kaidah keilmuan geografi yang benar. Selain itu, harus sesuai dengan tujuan pembelajaran geografi yang dikehendaki kurikulum. Kemudian, pemerintah dalam hal ini Pusat Kurikulum dan Perbukuan Kementerian Pendidikan dan 
Kebudayaan perlu membuat aturan (regulasi) yang ketat bagi penulis dan penerbit buku teks geografi.

Penulisan buku teks geografi harus mengacu pada prosedur yang jelas, misalnya dapat mengacu pada prosedur penulisan buku teks yang dikembangakn oleh Purwanto (2001) berikut:

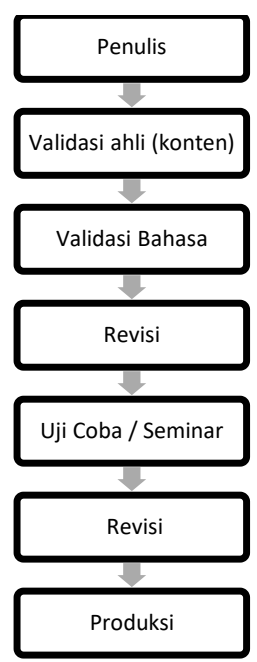

\section{Bagan 1.1 Prosedur penulisan buku teks (Purwanto, 2001)}

Dari bagan 1.1 dapat diketahui bahwa sebelum buku teks diproduksi (cetak) penulis harus melewati beberapa tahapan, yaitu: validasi buku teks, meliputi: validasi konten (isi) materi dan validasi penggunaan bahasa. Validasi harus melibatkan para pakar di bidangnya. Hal ini untuk menghindari terjadinya kesalahan konsep serta konten (isi) materi yang tidak sesuai dengan tujuan kurikulum.

Sebelum diterbitkan buku teks perlu dilakukan uji coba lapangan. Hal ini bertujuan untuk mendapatkan masukan dari calon pengguna buku teks (guru dan siswa). Selain itu, produk buku teks harus diseminarkan sebelum terbit. Hal ini bertujuan untuk meminta masukan dari praktisi, akademisi, dan guru mengenai produk buku teks yang sudah dibuat (Purwanto, 1999). Setelah semua proses tersebut dilalui, penerbit buku teks geografi baru diberikan izin untuk memproduksi.

\section{KESIMPULAN}

Setelah dilakukan analisis, buku teks geografi SMA karangan K. Wardiyatmoko memiliki kelemahan dalam hal konten (isi).Sebagian besar mengandung fakta dan konsep. Selain itu, aspek bahasa juga terdapat kelemahan, diantaranya banyak ditemukan paragraf yang terdiri dari dua kalimat. Kemudian, terdapat pula paragraf yang mengandung lebih dari satu konsep dan ide pokok sehinnga sulit dipahami oleh pembaca.

Kelemahan buku teks tersebut akan berdampak besar bagi dunia pendidikan (khususnya dalam pembelajaran geografi). Siswa akan kesulitan memahami konsep geografi untuk diaplikasikan dalam kehidupan sehari - hari. Kondisi ini membuat lulusan SMA akan sulit beradaptasi dan bersaing di era globalisasi pada abad 21 ini. Hal ini sangat miris apabila tidak dilakukan perbaikan.

Mengingat pentingnya buku teks yang berkualitas, diharapkan kepada akademisi, praktisi pendidikan geografi perlu dilakukan penelitian pengembangan untuk mendesain teks berbasis problem solving. Hal ini bertujuan untuk mempersiapkan generasi yang mampu 
berfikir kritis dan analisis di tengah pesatnya perkembangan ilmu pengetahuan dan teknologi yang menuntut lulusan dari institusi pendidikan memiliki kecerdasan majemuk.

Dalam mendasain teks berbasis problem solving, paling tidak dapat dilakukan dengan beberapa cara, dintaranya: pada setiap bab dalam buku teks geografi, dapatdiintegrasikan permasalahan yang dekat dengan lingkungan siswa. Misalnya pada bab sumber daya alam di Indonesia, setelah disajikan konsep dan fakta, penulis perlu menyajikan permasalahan eksploitasi sumber daya alam secara berlebihan yang merusak lingkungan. Kemudian, dapat juga disajikan permasalahan penggunaan energi fosil secara berlebihan yang berdampak pada ancaman perubahan iklim global (Aksa, 2016).

Pernyajian permasalahan pada setiap babdalam buku teks geografi akan membantu guru dalam mengelola pembelajaran berbasis masalah di kelas. Sehingga pada akhirnya, membuat pembelajaran geografi akan sangat menyenangkan. Siswa tidak dipaksa untuk menghafal konsep dan data tetapi mengasah kemampuan berfikir kritis.

\section{DAFTAR PUSTAKA}

Aksa, F.I. 2016. Development Of Geography Teks Book Model Book World Geography. Jurnal Ilmiah Ilmu Sosial, 2(1): 1-9.

BSNP. 2006. Instrumen Tahap II Penilaian Buku Teks Geografi SMA/MA. Jakarta: Departemen Pendidikan Nasional.

Diknas.2004. Pedoman Umum Pemilihan dan Pemanfaatan Bahan Ajar. Jakarta: Ditjen Dikdasmenum.

Harley. J. 1996. Text Design, In Jonassen, David. H, Handabook of Research For Education Communication and Technology. A Profect Of The Association For Education Communication And Technology.

Harper, R. 1990.The New School Geography: A critique. Journal of Geography, 89(1), 2730.

Husen, A.dkk. 1998. Telaah Kurikulum dan Buku Teks.Jakarta: Depdikbud.

Jitendra, Nolet, Xin, Gomez, Renouf, Iskold, \&DaCosta (2001) An Analysis Of Middle School Geography Textbooks: Implication For Students With Learning Problem.

Reading \& Writing Quarterly: Overcoming Learning Difficulties, 17:2, 151-173, DOI:10.1080/105735601300007606.

Kemp, J., Mellor, A., Kotter, R., \& Oosthoek, J.W. 2012. Student-produced podcasts as an assessment tool: An example from geomorphology. Journal of Geography in Higher Education, 36, 117-130.

Lee, J., \& Catling, S.2016. Some perceptions and practices of English geography textbook authors.International Research in Geographical and Environmental Education, $25,5067$.

Moisey, S.D 2001.An Integrated instructional design approach for fostering lasting behavioral change. Education Technology. 41 (2): 60-62.

Purwanto, Edy.Dkk 1996. Validasi Bahan Ajar IPS-Geografi SD Berdasarkan Kurikulum 1994 di Jawa Timur.Malang: Lemlit IKIP MALANG.

Purwanto, Edy \& Sumarmi. 2000. Pencitraan Bahan Ajar IPS-Geografi SLTP Yang disusun Berdasarkan Kurikulum 2004, Forum Penelitian Kependidikan, 12(2): 181-192.

Purwanto, Edy. 2001. Mengkaji Buku Pelajaran IPS Geografi Untuk Meningkatkan Kualitas Hasil Belajar. Jurnal Ilmu Pengetahuan Sosial, 34 (1): 24-25.

Purwanto, Edy.2005. Evaluasi Proses dan Hasil dalam Pembelajaran. Malang: UM PRESS. Shamir, A., Zion, M., Levi. 2008. Peer Tutoring, Metacognitive Processes and Multimedia Problem-based Learning: The Effect of Mediation Trainingon Critical Thinking. Journal Science Education Technology. 17:384-398. 
Sugiyono. 2010. Metode Penelitian Pendidikan (Kuantitatif, Kualitatif, dan R\&D). Bandung. Penerbit Alfabeta.

Universitas Negeri Malang. 2010. Pedoman Penulisan Karya Ilmiah. Edisi Keempat. Skripsi, Tesis, Disertasi, Artikel, Makalah, Laporan Penelitian. Malang: Universitas Negeri Malang.

Waugh, D. 2000. Writing geography textbooks.In C. Fisher \& T. Binns (Eds.), Issues in geographyteaching (pp. 93-107). London: Routledge.

Walkington, H., Dyer, S., Solem, M., Haigh, M.,\&Waddington. 2017. A capabilities approach to higher education: geocapabilities and implications for geography curricula. Journal of Geography in Higher Education, DOI:10.1080/03098265.2017.1379060. 